УДК 343.137 .07

DOI https://doi.org/10.32837/pyuv.v1i4(29).422

\author{
О.М. Миколенко \\ orcid.org/0000-0003-2080-413X \\ доктор юридичних наук, \\ професор кафедри кримінального права, кримінального процесу та криміналістики \\ Одеського національного університету імені I. I. Мечникова
}

\author{
Н.В.Неледва \\ orcid.org/0000-0002-9317-512X \\ кандидат юридичних наук, \\ доцент кафедри кримінального права, процесу та криліналістики \\ Міжнародного гуманітарного університету
}

\title{
ТЕНДЕНЦІЇ РОЗВИТКУ НАЦІОНАЛЬНОГО ЗАКОНОДАВСТВА ПРО МЕДІАЦІЮ ТА МЕДІАТОРА У КРИМІНАЛЬНОМУ ПРОВАДЖЕННІ
}

Постановка проблеми. Одним з аспектів реформування кримінального процесуального законодавства України є розвиток альтернативних (позасудових) способів врегулювання конфліктів. Термін «альтернативне вирішення спорів» вперше було уведено у США для позначення сукупності позасудових недержавних механізмів вирішення спорів [1, с. 6]. Альтернатива класичній судовій формі захисту була спрямована на розвантаження судової системи і протидію таким негативним тенденціям у сфері судочинства, як надмірна тривалість строків судового розгляду, занадто високі розміри судових витрат, а також складні та неефективні судові процедури. Серед таких альтернативних способів у кримінальному процесі України особливе місце займає медіація, тобто посередництво з метою укладання угоди про примирення між потерпілим та підозрюваним чи обвинуваченим. По-перше, медіація є одним із засобів гуманізації діючого законодавства, який максимально враховує інтереси громадянина - учасника кримінального провадження, по-друге, є правовою процедурою, що забезпечує реалізацію та ефективність альтернативного вирішення спорів на досудовому етапі або під час судового розгляду. У зв'язку з цим особливої актуальності набуває вирішення питань, які пов'язані з визначенням поняття «медіації» в профілюючому законодавчому акті - діючому КПК України, з закріпленням статусу органу, що здійснює процедуру медіації, з визначенням правового статусу медіатора у кримінальному процесі, а також питання щодо здійснення ефективного контролю за якістю послуг, які надають медіатори. I це не повний перелік питань, що потребують свого вирішення на теоретико-науковому і законодавчому рівнях. Вирішення ж цих питань є важливим для забезпечення ефективної роботи зазначеного інституту кримінального процесуального права. Саме тому медіація як явище правової дійсності потребує ретельного наукового обгрунтування та супро- воду під час практичного впровадження у кримінальний процес.

Аналіз останніх досліджень i публікацій. Питання щодо запровадження i ефективної дії інституту медіації досліджувалось різними вченими, кожен з яких аналізував особливості запровадження цього інституту в Україні. Окремі питаннязастосуваннямедіаціївкримінальномупроцесі були предметом дослідження таких вчених, як Х. Алікперов, А. Анцупов, А. Арутюнян, Ю. Баулін, О. Белінська, А. Біцій, Л. Володіна, І. Войтюк, А. Гайдук, Л. Головко, О. Губська, В. Землянська, Р. Коваль, Л. Лобанова, В. Маляренко, Л. Панов, Л. Сало, 3. Смітієнко, 3. Симоненко, І. Курляк, Н. Турман, В. Трубников, А. Шипилов й інші. Проте залишається необхідність у дослідженні медіації як явища у кримінальному провадженні (зокрема, чинників, які впливають на ефективність медіації у кримінальному провадженні, примирення як складника медіації та кримінального процесуального статусу особи медіатора тощо).

Постановка завдань. Основними завданнями, розв'язанню яких присвячена ця стаття, є такі:

1) дослідити хронологічні та змістовні аспекти розвитку національного законодавства про медіацію та медіатора у кримінальному провадженні;

2) виявити особливості та здійснити порівняльний аналіз участі у медіаційних процедурах адвоката та медіатора, як нового учасника кримінального провадження.

Виклад основного матеріалу. 3 кожним роком все більше уваги у науковій літературі приділяється альтернативним (позасудовим) способам врегулювання конфліктів та таким поняттям, як «відновне правосуддя», «посередництво», «медіація» або "примирення». Всі ці терміни, так чи інакше, знайшли своє закріплення як у національних нормативних актах або законопроектах, так і міжнародних актах європейського та світового рівня. 
Протягом останніх десятирічь медіація успішно розвивається в багатьох країнах світу. В США, Канаді, Австрії, Великобританії, Німеччині, Норвегії, Фінляндії, Франції та інших європейських країнах прийняті спеціальні закони, які захищають право медіатора на нерозголошення інформації, отриманої від сторін в процесі медіації [2, с. 131]. В деяких країнах прийняті спеціальні юридичні норми, згідно з якими сторони до моменту безпосередньої участі в судовому процесі повинні спробувати вирішити свій спір шляхом медіації. Також практика медіації поширюється і в країнах Східної Європи та колишніх республіках Радянського Союзу. Значний досвід з цього питання мають Польща, Албанія, Росія та інші країни.

Досвід країн світу дозволяє виявити наступні преваги інституту медіації. По-перше, участь сторін у цій процедурі вирішення конфліктів $€$ добровільною. Учасник будь-коли може припинити переговори та медіаційні відносини за власним бажанням. По-друге, посередництво в медіаційній процедурі вимагає менших фінансових і часових затрат. По-третє, таке посередництво уникає протистояння між сторонами, а тому краще сприймається учасниками правовідносин, ніж традиційний судовий процес. Таке посередництво є короткотривалим, не ворожим та орієнтованим на виконання завдання щодо розв'язання конфлікту. Ще однією перевагою медіації є її конфіденційність, яка є додатковою гарантією забезпечення та захисту прав учасників кримінального провадження [3].

Слід зазначити, що вже багато років в Україні обговорюється необхідність прийняття закону про медіацію. На розгляд парламенту було подано кілька проектів, які не знайшли підтримки народних депутатів. Одним 3 перших був законопроект «Про медіацію» від 27 березня 2015 р. № 2480 [4], якій був підготований народними депутатами України А.I. Шкрум, О.I. Сироїд, В.Ю. Пташником та іншими. В законопроекті медіатор розглядався як особа, яка відповідає вимогам, встановленим цим законом та медіаційним застереженням (угодою про медіацію), яка має статус медіатора відповідно до цього закону і яку сторони спору обрали для проведення медіації (ст. 2).

Згідно зі ст. 13 цього законопроекту медіатором може бути фізична особа, яка досягла двадцяти п'яти років, має вищу або професійно-технічну освіту та пройшла професійне навчання медіації, що має включати 90 академічних годин початкового навчання, в тому числі не менше 45 академічних годин навчання практичним навичкам. Додаткові вимоги щодо набуття статусу медіатора за спеціалізацією можуть встановлюватися законами України, організаціями, що забезпечують проведення медіації, об'єднаннями медіаторів.

Ще один законопроект «Про медіацію» від 17 грудня 2015 р. № 3665 був розглянутий у другому читанні, але 28 лютого 2019 р. відхилений Верховною Радою України [5]. Вимоги щодо медіатора такі ж самі, як і у попередньому проекті, адже розробниками є ті ж самі народні депутати. Додаткові ж вимоги щодо набуття статусу медіатора вже не були передбачені у зазначеному проекті.

5 липня 2019 р. народним депутатом Ю. Мірошніченко було подано законопроект, який має назву: «Про діяльність у сфері медіації» № 10425 [6]. Але цей законопроект був знятий з розгляду у зв'язку з розпуском Верховної Ради. Медіатором за законопроектом № 10425 є спеціально підготовлений посередник, який сприяє сторонам конфлікту (спору) в його врегулюванні шляхом структурованого переговорного процесу. I вимоги щодо особи медіатора вже зовсім інші. Так, медіатором може бути фізична особа, яка досягла 30 років, має вищу освіту та пройшла спеціальну підготовку у Всеукраїнській школі медіаторів або в інших акредитованих Радою медіаторів України закладах в Україні чи за iї межами. Стандарти та обсяги підготовки і підвищення квалірікації кадрів для медіації, а також відповідні навчальні програми затверджуються Радою медіаторів України. Спеціальну підготовку у сфері медіації здійснюють юридичні особи будьякої форми власності та організаційно-правової форми, у тому числі навчальні заклади, одним із видів діяльності яких є діяльність з професійного спеціального навчання медіаторів (ст. 10).

Останній законопроект «Про медіацію» було зареєстровано 28 грудня 2019 р. за № 2706, ініціатором розробки якого є Премьер-міністр України О.В. Гончарук [7]. Медіатором у цьому законопроекті визнається незалежна, нейтральна, неупереджена фізична особа, яка проводить медіацію i не має повноважень щодо прийняття рішення по суті конфлікту (спору). Медіатором може бути фізична особа, яка має вищу освіту та пройшла базову підготовку у сфері медіації в Україні або за їі межами. Як бачимо, законопроект не містить вимог щодо віку медіатора, але визначено: «Сторони медіації, державні органи та органи місцевого самоврядування можуть встановлювати додаткові вимоги до медіаторів, яких вони залучають або послугами яких користуються, у тому числі щодо віку, освіти, досвіду роботи. Об'єднання медіаторів та організації, що забезпечують проведення медіації, можуть встановлювати додаткові вимоги до медіаторів, яких вони включають до своїх реєстрів» (ст. 9) .

На наш погляд, таке встановлення додаткових вимог до медіаторів призведе лише до створення «закритих клубів», де засновники замість ефективної роботи будуть придумувати нові вимоги $\mathrm{i}$ нові правила гри, а в кінцевому рахунку це призведе до монополізації цього інституту та його корумпованості. 
Ще декілька важливих питань: які саме права та обов'язки має медіатор у кримінальному провадженні?; чи може захисник підозрюваного (обвинуваченого) або представник потерпілого приймати участь у медіаційному процесі?; якщо так, то в яких саме межах?

У сучасній юридичній літературі питаннями участі адвокатів у медіації присвячені праці А. Понасюка, М. Семеняко, А. Біцій. У зазначених працях висвітлюються окремі аспекти участі адвоката у процедурі посередництва як медіатора.

Особливості участі адвоката в урегулюванні правових спорів (юридичних конфліктів) як медіатора, на думку А. Понасюка, проявляються у таких ознаках: 1) особлива предметна сфера діяльності адвоката, пов'язана з глибоким всебічним аналізом протиріч і відносин у конфліктах різних предметних категорій; 2) особлива роль адвоката як незалежного та неупередженого посередника, який сприяє сторонам в пошуку взаємоприйнятних та взаємовигідних умов припинення спору; 3) особлива процедура (медіація), в рамках якої може здійснюватися адвокатська діяльність, і місце адвоката-медіатора в цій процедурі [8, с. 148].

Якщо з першою ознакою участі адвоката у медіаційній процедурі (але не в якості медіатора) слід погодитися, то дві наступні є дискусійними та викликають сумніви щодо їх переконливості.

Так, угода про примирення між потерпілим та підозрюваним чи обвинуваченим може бути укладена у провадженні щодо кримінальних проступків, злочинів невеликої чи середньої тяжкості та у кримінальному провадженні у формі приватного обвинувачення (ч. 4 ст. 469 КПК України), тільки за добровільною згодою сторін. У разі, коли підозрюваний чи обвинувачений виявить бажання примиритися с потерпілим, відшкодувати завдану ним шкоду, нормалізувати відносини 3 потерпілим, а потерпілий - пробачити підозрюваного / обвинуваченого, отримати від нього відшкодування та відновити стосунки, адвокат повинен поінформувати свого клієнта щодо укладання угоди про примирення на підставі ст. 469 КПК України та примирення з потерпілим на підставі ст. 46 КК України. Ініціатором примирення також може бути і потерпілий, і в цьому разі адвокат так само роз'яснює своєму клієнту його права. Тобто роль адвоката полягає у наданні професійної допомоги особі як захисника чи представника щодо роз'яснення можливості ініціювання, організації та проведення процедури медіації, прав сторін, можливих правових наслідків досягнення певної домовленості між сторонами та наслідків невиконання цих домовленостей. Повністю підтримуємо думку А. Біцай стосовно того, що адвокату слід рекомендувати клієнту взяти участь у примирній зустрічі з підозрюваним чи обвинуваченим, якщо це сприятиме психологічному «зціленню» по- терпілого як жертви злочину, а також дозволить йому швидше і в повному обсязі отримати відшкодування заподіяної злочином шкоди [9, с. 8-14].

Особливу роль адвоката як незалежного та неупередженого посередника, який сприяє сторонам в пошуку взаємоприйнятних та взаємовигідних умов урегулювання спору, вважаємо досить спірною. У цій ситуації адвокат повинен змінити стереотип мислення, сконцентрувати свою увагу не тільки на правових позиціях клієнта, але i на інтересах, які приховані за цими позиціями. Адвокат повинен вміти перейти від звичайної для нього стратегії змагальності до вміння застосовувати стратегію консенсусу чи компромісу у взаємовідносинах з іншою стороною спору. Наскільки це можливо для особи, яка звикла «перемагати» в процесуальному протистоянні, чіпляючись за юридичні факти, що свідчать про порушення форми кримінального процесу, спростовують докази винуватості підозрюваного (обвинуваченого) тощо? Сумніваємось, що така особа спроможна перейти на рівень надання посередницьких послуг. Наприклад, О. Яновська, А. Біцай з цього приводу зазначають, що юридично мислячим посередникам доволі важко дається надання сторонам свободи. Юрист має здатність, звички і навіть амбіції до оперативного аналізу та вирішення заплутаних проблем, тому він схильний обмежувати автономію сторін і втручатися в переговори з власними пропозиціями [10, с. 21-23]. Але ж йому необхідно забезпечувати усім сторонам правового спору рівні можливості, діяти на рівних засадах та виконувати роль модератора, який направляє сторони до узгодження спірних питань. Адже головним завданням адвоката в медіаційній процедурі буде не доказування обгрунтованості позиції клієнта іншій стороні спору, а узгодження інтересів клієнта 3 іншою стороною, що необхідно для взаємовигідного вирішення спору між сторонами.

Така ж позиція простежується у законопроекті «Про медіацію» від 27 березня 2015 р. № 2480, де у ст. 17 «Незалежність медіатора» зазначено, що медіатором не може виступати адвокат, представник та/або законний представник сторони медіації. Особа не може виступати адвокатом або представником сторони медіації у справі (провадженні), в якій вона надавала або надає послуги медіатора [4].

Подібне положення міститься і у законопроекті «Про медіацію» від 28.12.2019 р. № 2706 уст. 6 «Незалежність танейтральністьмедіатора»медіатор не може бути представником або захисником будь-якої із сторін у досудовому розслідуванні, судовому, третейському чи арбітражному провадженні у конфлікті (спорі), в якому він був медіатором [7].

Щодо останньої ознаки, у якій виявляються особливості діяльності адвоката як медіатора у 
процедурі медіації, то думки вчених діаметрально розділилися. Так, О. Яновська, А. Біцай вважають, що адвокати можуть бути присутніми i брати участь у процедурі медіації, якщо сторони заздалегідь досягнуть згоди з цього питання. У виборі в якості медіаторів представників юридичних професій вони вбачають такі переваги, як: володіння навичками «процедурної» гри та здатність передбачати юридичні наслідки укладеної угоди [9, с. 8-14; 10, с. 21-23].

Інші науковці вважають, що представлення інтересів потерпілого або підозрюваного чи обвинуваченого юристом-професіоналом суперечитиме власне концепції відновного правосуддя, де кожен із учасників говорить за себе і демонструє намір досягти домовленості або результату, за якого кожна сторона залишається у виграші, а не до традиційного для адвокатів результату, де одна сторона обов' язково програє [11, с. 110-112]. Не заперечуємо проти доступу сторін до консультації адвокатів до або під час заключення медіаційної угоди (угоди про примирення за ст. 469 КПК України), але участь адвоката поруч зі своїм клієнтом під час процедури медіації у кримінальних справах варто визнати недоцільною.

Висновки та перспективи подалыших розвідок. На підставі проведеного дослідження можна зробити такі висновки:

1. Всі законодавчі ініціативи щодо визначення місця та ролі медіатора в судових процесах, на жаль, не набули свого реального втілення у житті. Зумовлено це тим, що у політиків, теоретиків та юристів-практиків відсутнє єдине бачення щодо: а) вимог до особи-медіатора; б) об'єму прав та обов'язків, які він реалізує в межах кримінального процесу; в) юридичної відповідальності за порушення закону під час участі у медіаційній процедурі; г) організаційних форм медіаційних організацій тощо. Тому є нагальна потреба у прийнятті не тільки загального закону про медіацію, а й законів про внесення змін до кримінального процесуального законодавства, які б враховували специфіку здійснення медіаційної процедури у кримінальному провадженні.

2. Відсутність чітких вимог до особи медіатоpa, які повинні бути закріплені винятково на рівні законів, створює умови для зловживань та розквіту корупції. Інакше, встановлення додаткових вимог до особи медіатора на рівні підзаконних чи локальних актів призведе до створення так званих «закритих клубів», де засновники замість ефективної роботи будуть придумувати нові вимоги i нові правила гри для охочих вступити в їх ряди.

3. Основна відмінність адвоката і медіатора полягає в тому, що адвокат є фахівцем у галузі права, а медіатор - у психології та конфліктології. Поєднання в одній особі цих двох статусів (адвоката і медіатора) є недопустимим з таких причин: а) адво- кат у кримінальних процесуальних відносинах використовує стратегію змагальності, тоді як медіатор - стратегію консенсусу чи компромісу; б) адвокат відстоює лише інтереси одного з учасників процесу, тоді як медіатор намагається знайти злагоду між інтересами всіх учасників медіаційної процедури.

\section{Jimepamypa}

1. Носырева Е.И. Альтернативное разрешение споров в США. Москва, 2005. 320 с.

2. Альтернативні підходи до розв'язання конфліктів: теорія і практика застосування / Уклад. : Н. Гайдук, I. Сенюта, О. Бік, Х. Терешко. Львів : ПАІС, 2007. 296 c.

3. Подковенко Т.О. Альтернативні способи розв'язання юридичних конфліктів. URL: http:// dspace.tneu.edu.ua/bitstream/316497/8769/1/\% D0\% $90 \% \mathrm{D} 0 \%$ 9B $\%$ D0 $\%$ AC $\%$ D0 $\%$ A $2 \%$ D0 $\% 95 \%$ D0 $\%$ A0 $\%$

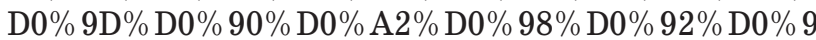
D $\%$ D0 $\% 86 \% 20 \%$ D0 $\%$ A1 $\%$ D0 $\%$ 9F $\%$ D0 $\%$ 9E $\%$ D0 $\%$ A $1 \%$ D0 $\%$ 9E $\%$ D0 $\% 91 \%$ D0 $\%$ 98 $\% 20 \%$ D0 $\%$ A0 $\%$ D0 $\%$ 9E $\%$ D0 \% 97\% D0 \% 92\% D0 \% AF\% D0 \% 97\% D0\% 90\% D0 $\%$ 9D $\%$ D0 $\%$ 9D $\%$ D0 $\%$ AF $\% 20 \%$ D0 $\% 9 \mathrm{~A} \% \mathrm{D} 0 \% 9 \mathrm{E} \% \mathrm{D} 0$

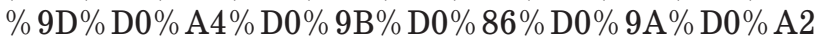
$\%$ D0 \% 86\% D0\% 92.pdf.

4. Проект Закону України «Про медіацію» від 27.03.2015 p. № 2480. URL: http://w1.c1.rada.gov.ua/ pls $/$ zweb2 $/$ webproc4_1?pf3511=54558.

5. Проект Закону України «Про медіацію» від 17.12.2015 p. № 3665. URL: http://w1.c1.rada.gov.ua/ pls/zweb2/webproc4_1?pf3511=57463.

6. Проект Закону України «Про діяльність у сфері медіації» від 05.07.2019 p. № 10425. URL: http:// search.ligazakon.ua/l doc2.nsf/link1/JH81L00A.html.

7. Проект Закону України «Про медіацію» від 28.12.2019 р. за № 2706. URL: http://w1.c1.rada.gov. ua/pls/zweb2/webproc4 1?pf3511=67831.

8. Понасюк А.М. Участие адвоката в урегулировании юридических споров посредством медиации : дис.... канд. юр. наук : 12.00.11 - судебная власть, прокурорский надзор, организация правоохранительной деятельности; Российская академия адвокатуры и нотариата (институт). Москва, 2011. 269 с

9. Біцай А.В. Участь адвоката в медіації у кримінальному провадженні у контексті реалізації права на справедливий суд. Вісник крилінального судочинства. 2018. № 2. C. 8-14

10. Яновська О., Біцай А. Особливості участі адвоката у процедурі медіації. Вісник Київського наиіонального університету імені Тараса Шевченка: Юридичні науки. Вип. 1 (99). 2014. С. 21-23.

11. Реконструкция связей в сообществе - медиация и восстановительное правосудие в Европе / И. Айртсен, Р. Маккей, М. Райт и др.; пер. с англ. Киев : Издатель Захаренко В.А., 2008. 183 с.

\section{Анотація}

Миколенко О. М., Неледва Н. В. Тенденції розвитку національного законодавства про медіацію та медіатора у кримінальному провадженні. - Стаття.

У роботі розкриті тенденції розвитку національного законодавства про медіацію та медіатора у кримінальному провадженні. Виявлені особливості та здійснено порівняльний аналіз участі у медіаційних процедурах адвоката та медіатора, як нового учасника кримінального провадження. Зазначається, що всі законодавчі ініціативи щодо визначення місця та ролі медіатора 
в судових процесах, на жаль, не набули свого реального втілення у житті. Зумовлено це тим, що у політиків, теоретиків та юристів-практиків відсутнє єдине бачення щодо: а) вимог до особи-медіатора; б) об'єму прав та обов'язків, які він реалізує в межах кримінального процесу; в) юридичної відповідальності за порушення закону під час участі у медіаційній процедурі; г) організаційних форм медіаційних організацій тощо. Зроблено висновок, що відсутність чітких вимог до особи медіатора, які повинні бути закріплені винятково на рівні законів, створює умови для зловживань та розквіту корупції. Встановлено, що основною відмінністю адвоката і медіатора є те, що адвокат є фахівцем у галузі права, а медіатор - у психології та конфліктологіі і поєднання в одній особі цих двох статусів (адвоката і медіатора) є недопустимим.

Ключові слова: кримінальний процес, спосіб врегулювання конфліктів, медіація, медіатор, правовий статус медіатора, адвокат, спеціаліст.

\section{Summary}

Mykolenko O. M., Neledva N. V. Tendencies in the development of national legislation on mediation and mediator in criminal proceedings. - Article.

Tendencies in the development of national legislation on mediation and mediator in criminal proceedings, are exposed in the work. There were revealed some peculiarities and a comparative analysis of participation in the mediation procedures of a lawyer and mediator as a new participant in criminal proceedings.

It was noted that all legislative initiatives as for determination of the place and role of the mediator in the lawsuits, unfortunately, were not implemented.

This happened because politicians, theorists and practitioners have a lack of common vision as for: a) the requirements for the mediator; b) the scope of rights and obligations that he/she (mediator) exercises in the course of criminal proceedings; c) legal responsibility for law violation during participation in mediation procedure; d) organizational forms of mediation agencies, etc. It was concluded that the lack of clear requirements for the mediator's personality which should be fixed exclusively at the level of the law, creates several conditions for abuse and flourishing of corruption.

It is established that the main difference between a lawyer and a mediator is that a lawyer is a specialist in the field of law and a mediator is in psychology and conflictology, and the combination of these both statuses (lawyer and mediator) in one person is unacceptable.

Key words: criminal procedure, method of conflicts resolution, mediation, mediator, legal status of mediator, lawyer, specialist. 